\title{
Applying Global Perspectives on Fragility to Improve US Communities
}

\author{
Debra J. Bolton ${ }^{1}$, Francisco M. Hernandez² \\ ${ }^{1}$ Southwest Research Extension Center, Kansas State University, Garden City, KS, USA \\ ${ }^{2}$ University of Kansas, Fort Leavenworth, KS, USA \\ Email: dbolton@ksu.edu, francisco.hernandez@ku.edu
}

How to cite this paper: Bolton, D. J., \& Hernandez, F. M. (2017). Applying Global Perspectives on Fragility to Improve US Communities. Advances in Anthropology, 7, 22-33.

https://doi.org/10.4236/aa.2017.71003

Received: December 8, 2016

Accepted: January 19, 2017

Published: January 22, 2017

Copyright $\odot 2017$ by authors and Scientific Research Publishing Inc. This work is licensed under the Creative Commons Attribution International License (CC BY 4.0).

http://creativecommons.org/licenses/by/4.0/

\begin{abstract}
Today, the greatest impacts on families stem from ongoing global conflicts and other natural or man-made disasters. Literature and multi-lingual research were examined and analyzed to determine fragility in rural and urban US communities with high immigrant populations, high poverty, and challenged social integration. Data came from international development and localized research. Literature review content was related to fragility, families emigrating to the US coming from those fragile states, and immigrants' ability to adapt to new environments as evidenced in research analyses. Approaches that non-governmental, humanitarian and peace-building entities are taking to bridge research with application were also examined. A model of adaptive and culturally-relevant practices is offered as a logical way to address the effects of poverty and fragile conditions, and to move affected populations toward resilience.
\end{abstract}

\section{Keywords}

Fragility, Poverty, Behavior, Conceptual Framework, Theory Development

\section{Introduction: Human Displacements}

The greatest impacts on families and their human rights stem from ongoing global conflicts, and other natural or man-made disasters. The result of these disasters includes alarming statistics on the number of forced displacements of affected populations (de Boer, 2015). Forced migrations include displacements because of persecution, armed conflict, generalized violence, human rights violations, natural or environmental disasters, famine, ineffectual governments, and the lack of financial opportunities each, having an impact on human behavior (Baker, 2014; Goetz, \& Rupasingha, 2007). According to the World Bank (2014), human displacement caused by conflict is the highest on record since World 
War II. "Forced displacement" is typically viewed as a humanitarian issue; however, it also has economic, social, political, and environmental impacts on the places of origin, as well as the receiving communities (Dozi \& Valdivia, 2005). Research on the impact of forced migration on those families and communities affected by conflict, violence, and poverty needs to be further refined when looking at US communities (Bolton \& Dick, 2016). Policies need to be enacted that will mitigate, reduce and prevent outbreaks of violence, conflict, isolation, and the effects of poverty (Hernandez \& Wright, 2015). Additionally, as a move toward cohesion, it is imperative that those affected groups be integrated to mainstream communities with great effort by institutions, education, and governance structures (Ramos, 2016).

In a mixed-methods approach, the authors examined literature and analyzed multi-lingual research to determine fragility in rural and urban communities with high immigrant populations, high poverty, and challenged social integration. Data came from international development research and localized multi-lingual studies. Qualitative literature review content was analyzed looking for items related to fragility, emigrating families to the US coming from those fragile states, and immigrants' ability to adapt to new environments. Also reviewed were the approaches that non-governmental, humanitarian and peace-building entities took to bridge research with application and practice. To conclude, we offer a model of adaptive and culturally-relevant practices as a logical way to address the effects of poverty and other fragile conditions thereby moving affected populations toward resilience.

\section{Defining "Fragile States"}

Fragile states, unlike stable and functioning states, often face formidable obstacles to stability, development and democracy, creating social divisions that hinder programs to improve governance and economic opportunities (Kaplan, 2016). A fragile state, as described by Dr. Pauline Baker (2015), fails to carry out basic governing functions, manage pressures and shocks to human systems, and fails to be responsive to the changing social dynamics of its citizens. As social, economic, political, environmental, and other natural or man-made risks aggregate, systems are ill-equipped and lack the capacity to respond adequately to such pressures. These conditions may lead to increased vulnerability in populations at risk of extreme poverty, violence and exclusion (de Boer, 2015). The interactions and relationships between individuals, communities, and institutions, or lack thereof, determine the state of fragility (Kaplan, 2016).

The Fund for Peace, in Washington, D.C., ranks countries based on Demographic Pressures, Refugees and Internally Displaced Persons, Group Grievance, Human Flight, Uneven Economic Development, Economic Decline, State Legitimacy, Public Services, Human Rights \& Rule of Law, Security Apparatus, Factionalized Elites, and External Intervention (Fund for Peace, 2016). Rankings go from \#1 as Very High Alert (Somalia) to Very Sustainable \#, in which Finland stands alone. The United States is ranked Very Stable at \#159, which it shares 
with Spain \#153 to United Kingdom \#162.

Today, we see government failures from local through national levels in providing adequate, perceived and actual, social justice functions, economic opportunities and inclusive social programing and policies, all of which are drivers of fragility. Likely, US communities would not be considered as failed governments, but many lack in social justice functions (protection for vulnerable children, access to clean water and adequate educational systems), economic opportunities, inclusive social programming (aid to families living in poverty), and high poverty. Data in the Failed State Index or "FSI" (Fund for Peace, 2016), was analyzed by the international development community targeting underdeveloped and fragile countries, and show that these same indicators can be applicable within urban, rural and other underdeveloped US communities receiving displaced populations (See Figure 1). The measurement of success in moving populations away from vulnerability and toward self-sufficiency came from the

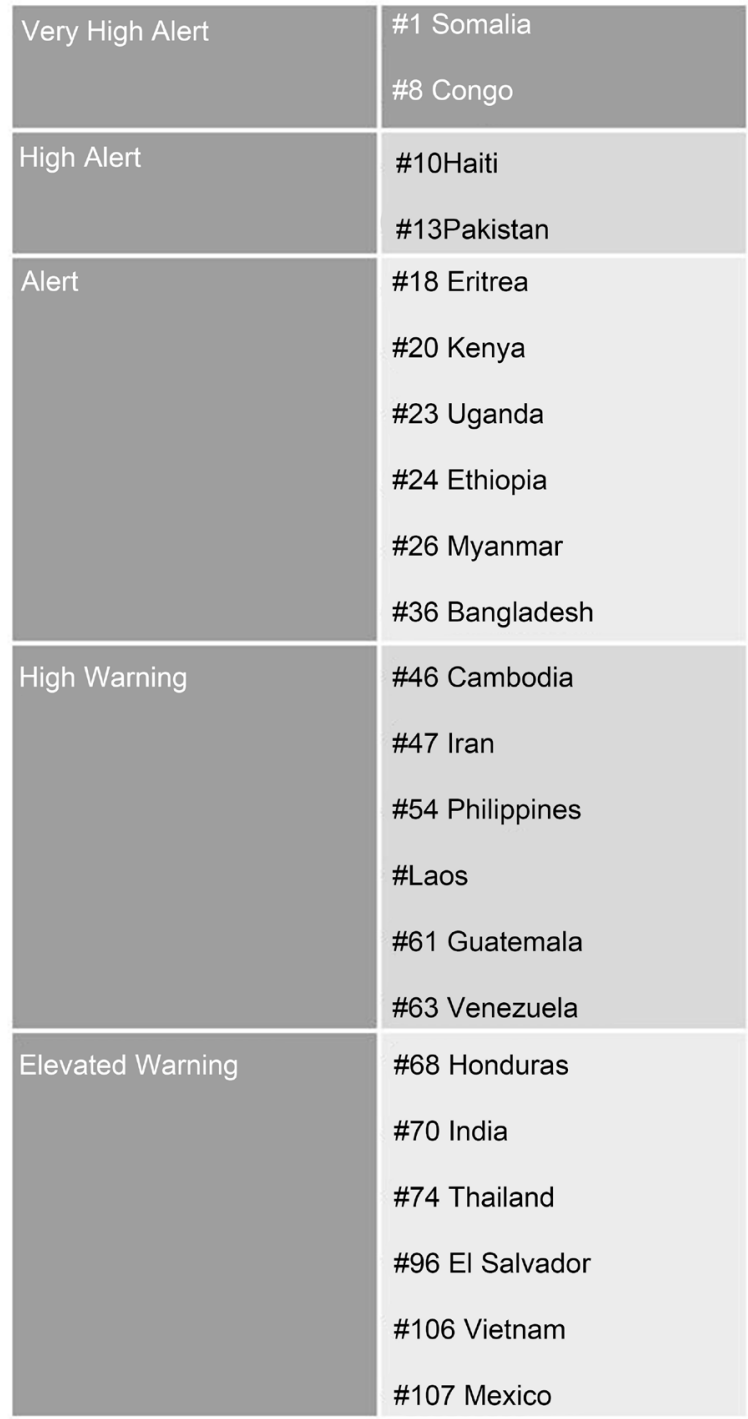

Figure 1. Country of origin of immigrants and refugees currently resettling in the midwest of the United States. 
Organization for Economic Cooperation Development's (OECD) Millennium Development Goals of reducing persistent poverty and infant mortality, and increasing access to clean water (OECD, 2015). Similar to those countries deemed as "fragile", varying levels of fragility can be observed in US communities. Refugees and other immigrants are settling into receiving communities of the Midwest. Those cities and townships provide jobs and continue to provide opportunities to families coming from countries marked by violence, poverty, failed governments, and zero employment opportunities. For example, Kansas, Nebraska, and Minnesota have settlement of refugee families from Somalia, currently ranked \#1, very high alert, in the Fragile States Index. It is safe to say that refugees coming to a country to find peace and economic opportunities have demographic pressures, are displaced, and are in a fragile state. How families handle the shocks to their systems depends on how receiving communities assist them in their integration (Ramos, 2016). The table, Figure 1, illustrates the origin of populations within the United States, specifically the Midwest, which are products of countries with significant rankings in the Fragile States Index. Families coming from countries ranked from Very High Alert to Elevated Warning, are coming with great vulnerabilities and would benefit from a multi-system intervention approach.

While fragility most often describes some under-developed countries, economic inequalities were described and outlined in 50 of the United States' largest cities (Berube, 2014) as families living in the poorest households have seen their wages stagnate or decrease over the past 35 years with average annual household incomes hovering around $\$ 18,100$ for a family of three. The 2016 Federal Poverty Guidelines

(https://www.parkviewmc.com/app/files/public/1484/2016-Poverty-Level-Chart.p df) illustrate that a family of two earning $\$ 15,930$ lives at $100 \%$ of poverty. The US infant mortality rate is equally as bleak as it lags behind Finland, Sweden, Norway, Korea, Germany, United Kingdom, Canada, and 19 other countries (Ingraham, 2014). Access to clean water has been a challenge for US families as well.

The Environmental Protection Agency regularly releases fact sheets and drinking water advisories for microbial contaminants

(https://www.epa.gov/dwstandardsregulations/drinking-water-contaminant-huma n-health-effects-information), July 2016) in which many US cities are cited. Most recently, the Flint, Michigan water crisis put unsafe drinking at the forefront when community members had been consuming water with such contaminants as fecal coliforms. Flint's poorest communities were hit the hardest (http://www.cnn.com/2016/03/04/us/flint-water-crisis-fast-facts/, July 2016). All are on-going crises that further illustrate fragility within U. S. communities.

\section{Drivers of Fragility}

Of the many indicators driving violence and conflict, those most notable in this context include loss of state legitimacy, extreme poverty, lack of educational op- 
portunities, and social isolation. Globally and in US communities, a state's inability to provide for the essential needs of its citizens, protection from human rights violations, social exclusion, legitimate social justice programs, and access to living wages or educational opportunities, significantly damages the credibility of governmental institutions with local populations. Cohesive societies, from the individual through the state level, have shown that they are better able to manage and react to environmental conditions and shocks (Kaplan, 2016). Internationally, data from 2015 estimated that $50 \%$ of "fragile state" populations lived on or under \$1.25USD a day (Hernandez \& Wright, 2015).

Additional data suggest that extreme poverty also significantly increases the likelihood of violence, poor health, low educational attainment, and armed conflict as a result (Baker, 2014; Flora \& Flora, 2015; Bolton \& Dick, 2016). In the international arena, the aggregation of populations in these poor and, frequently, violent-ridden areas also places an undo strain on the capacity of the affected governments and institutions to provide adequate services in response to those conditions (de Boer, 2015). While this level of extreme poverty appears only to be a global issue tied to failed or failing states, millions of families and households in the United States also experience the effects of fragility. Fragility also includes populations who lack political voice in the policies that affect them (Woolcock \& Narayan, 2000; Ramos, 2016).

\section{Impacts of Poverty and Social Exclusion}

This article explores indicators of fragility used by government, non-government, humanitarian and peace-building organizations worldwide, and applies those concepts to US communities with high poverty and persistent isolation of affected populations. In US communities with persistent poverty (individuals and families living at $100 \%$ of poverty or below), low employment, and decreased income can create fragile conditions for families, making them vulnerable and at a higher risk of negative behavioral responses (Hernandez \& Wright, 2015, Bolton \& Dick, 2016; Dozi \& Valdivia, 2005). The Failed State Index (FSI) looks at social, economic, and political/military indicators to measure human well-being (Baker, 2015). Historical and current population demographics must be considered in the context of fragile settings; particularly because communities with persistent poverty, historically, tend to be comprised of minority populations (Kaplan, 2016).

In 2016 (Bolton \& Dick), a multi-lingual (English, Spanish, Somali, and Burmese) study focused on the health, well-being, and social connectedness of a densely-settled rural, Midwest, community with Minority-majority populations. To-date, the follow-up study is in analyses for completion in early 2017. It is from the 2013 study that researchers identified conditions that reflected fragility. The data analyses contained in this study were limited to: Frequencies, Test of Proportions ( $t$-test), Test for Independence $\left(X^{2}\right)$, Ethnographic examples, and Qualitative Interviews. Primarily, in bi-variate analysis ( $p$-values less than 0.0001), non-Anglo, foreign-born respondents appeared to be living in fragile 
conditions.

Of those not born in the US $68 \%$ had either a high school diploma or fewer years of education, which represents an undereducated populace when linking education to employment. However, $64 \%$ of the respondents acknowledged that further education would help to improve their living conditions. Also, respondents indicated that they observed a lack of opportunities or barriers to attaining higher education. While non-Anglo respondents appeared to be a trusting group (of others not like themselves), 95\% of respondents reported a lack of political voice. Isolation was indicated by $84 \%$ of non-Anglo respondents who were not involved in service organizations. However, $78 \%$ volunteered informally, for example, by doing favors for neighbors ranging from childcare to house repairs. Poverty was indicated when $80 \%$ of respondents reported income ranging from $\$ 12,000$ to $\$ 24,999$ annually for an average family of four, which would be $100 \%$ of poverty as reported by Federal Poverty Guidelines. In the quadrant of the state where this study took place, the three population-centers, today, are Minority-majority and continue to grow in that vein. Researchers continue to see the effects of low-educational attainment, social and political isolation, and poverty (Bolton \& Dick, 2016; Hernandez \& Wright, 2015), which are drivers of fragility. See Figure 2.

A 2015 Mercy Corps study states that poverty, specifically, does not necessarily correlate to violence. However, when poverty is coupled with injustice, it can lead to discrimination, disenfranchisement, corruption and economic deprivation; each a driver of fragility (Baker, 2015). Real and perceived injustices, in those matters in which groups feel they have been mistreated, or treated unfairly, can also influence the outcome of programs to improve conditions (Kaplan, 2016). In that, governments and organizations recognize that they have critical roles in promoting programs in fragile environments to bolster resilience and build inclusive opportunities for affected populations (de Boer, 2015). In looking at efforts to target those most at-risk populations, we must consider programing to improve economic growth and inequality, which encompass the subset - injustice. Economic growth programs to improve quality of life within homes and communities tend to increase stability, and efforts to reduce inequalities have shown to improve resiliency and limit social exclusion (Baker, 2015).

Should the United States continue its growing ethnic and cultural diversity trajectory, it will become a minority-majority country by 2043 (Hernandez \& Bolton, 2015; Hernandez \& Wright, 2014). However, market and economic analyses of the 2014 Census found accelerated growth of the rich-poor divide,

\begin{tabular}{|c|c|c|c|c|}
\hline Respondents & $\begin{array}{l}\text { High School or } \\
\text { fewer years }\end{array}$ & $\begin{array}{l}\text { Know education would } \\
\text { improve family situation }\end{array}$ & $\begin{array}{l}\$ 12,000- \\
24,000 \\
\text { annual } \\
\text { income }\end{array}$ & $\begin{array}{l}\text { Lack Political } \\
\text { voice }\end{array}$ \\
\hline Not born in U.S & $68 \%$ & $64 \%$ & $80 \%$ & $95 \%$ \\
\hline
\end{tabular}

Figure 2. Results of localized multi-lingual study. 
showing that $36 \%$ of non-Whites are members of the economic lower-class as compared to $16 \%$ of Whites (US Census, 2014). Additional Census data show that Whites comprise a disproportionately higher percentage of the economic middle-class and above and account for the majority of higher-income earners. These socioeconomic statistics illustrate inequality, social exclusion, and a state of fragility, real and perceived. We must identify a means to reach those fragile states within US borders or risk further disenfranchisement (Hernandez \& Bolton, 2015).

In its report on the "States of Fragility and Sustainable Development Goals," the Organization for Economic Co-operation and Development (OECD) suggested that a universal approach to assessing fragility has multiple benefits. It can help to identify priorities by highlighting populations that are vulnerable to specific risks. Further, it can inform community human service priorities for collaboratively mitigating and reducing fragility for families and individuals (OECD, 2015). The adoption of an Adaptive and Culturally-Relevant Practices Framework, targeting individuals, communities, and institutions, may be appropriate as a guide for what could work in helping families move out of fragility and toward a quality of life that reflects resilience and self-actualization. In the end, communities become cohesive, and individuals and families thrive in social and economic situations (Hernandez \& Wright, 2014).

\subsection{Conceptual Frameworks to Combat Fragility}

While fragile states are associated mostly at a country level application, looking at how family dynamics are impacted within fragile settings also is reasonable. Limited or lack of employment and income generating opportunities, social isolation, poor health, and barriers to educational opportunities put families at risk, cause stressors, and contribute to environmental shocks for families. These experiences, at the family and/or community level, create a fragile state. "Micro-shocks" can include a sudden loss of a job; while macro-level shocks result from implementations or changes of national policies. The FSI provides a foundation for identifying the factors that make societies fragile (Baker, 2014; World Bank, 2011). Institutions, organizations, and businesses employing Corporate Social Responsibility (CSR) were found to have approaches that benefit populations challenged by environments of fragility. Successful organizations practicing CSR offer better access to health, education and economic opportunities for those in greatest need. Looking to new approaches to improve fragile environments, it is critical that it not be top-down implementation. Rather it requires a delicate balance of inputs and influences from communities and individuals in the targeted areas.

\subsection{Partnerships in the Private Sector}

While formal and informal education continues to be a strong in the development of fragile communities, increased collaboration with the private sector is another approach gaining wide acceptance in international development circles 
(Hernandez \& Wright, 2015; Hernandez, 2016). As private industry looks to new programs and markets in which to expand their shared-value approaches, it presents tangible benefits to all stakeholders, which shows an ability to provide sustainable growth and vitality across various development sectors. Internationally, US government organizations are increasingly reliant upon the private sector to help meet developmental objectives, such as reducing violence, poverty and security threats. By looking inside US borders, the application of similar approaches by local governments for the benefit of its populace could provide those shared-value approaches and positive returns-on-investments (ROI) between government, community and business (Hernandez, 2016). The creation of these partnerships and human and market value-chains help build the trust necessary for successful program implementation. Also, it increases opportunities for other programing, such as those targeting other at-risk sectors: education, health, security and justice. As we look to new ways to promote community resilience and combat fragility, we must not discount what has demonstrated to be successful in the international community.

\subsection{Education and Educational Institution Partnerships}

1992 Nobel Laureate, Gary Becker, who popularized human capital and its relationship with economic growth theory, discussed how economic discrimination is partially driven by the inability of the lower class to attain and provide marketable skills through proper education. National security strategies, international development agendas, and educational outcomes are designed to address the socioeconomic challenges faced by millions of families who continue to face poverty related to conflict, violence, and ineffectual governance. In an effort to combat fragility with targeted programming in the $21^{\text {st }}$ Century, we have opportunities and obligations to support families in maintaining or re-establishing their wellbeing to into community dynamics, and increase their resiliency to outside stressors and shocks.

Educators can help shape environments to mitigate fragility by targeting and confronting those external and internal environmental risk factors, such as market conditions, that influence market and human capital value chains. Education programs and policies, designed to improve the human capital development of individuals to integrate into these value chains, could address interventions that decrease fragility and support social and economic inclusion. Successful human capital development strategies must target lower-income demographic groups, and other underrepresented populations and communities, providing the required skills leading to market inclusion in economic value chains (Michel, 2014). Equipping those individuals in fragile communities with marketable job skills should be a strategic goal for the development and growth of those most affected by the growing economic divide separating our society (Hernandez \& Wright, 2015). At the 2016 Kansas Health Foundation Symposium, the $17^{\text {th }}$ Surgeon General of the United States, Richard Carmona, said, "When you invest in the poor, you create tax payers", a valuable argument in 
mitigating fragility.

\subsection{Model Development to Overcome Fragility}

An effort to overcome the factors influencing community-level fragility, policy makers and program developers have thus far utilized various approaches based on the desired outcomes. Efforts can be strengthened with human domain-centric, long-term programs targeting those families and communities most at risk of being negatively affected by shocks and stressors to their environments. Concentrated attempts would also help to build resiliency while providing economic opportunities. Though the desired end-states vary, the global objective remains the same: Promote well-being and peace, and engage citizens by giving them tools to overcome those factors influencing conflict, violence, poor health, low education, and lost opportunities.

\section{Recommendations on Research}

As society becomes more ethnically pluralistic, the ability of individuals, communities, and institutions to function within their system will become increasingly more dependent on their abilities to build and maintain trust, improve interconnectedness, and remain adaptable to changing social, economic, and political landscapes. Initiatives, targeting the challenges of fragility, must be developed, funded, and implemented with the buy-in of individuals, communities and institutions working to improve sustainability and socioeconomic progress (Hernandez \& Bolton, 2015).

Coordinating initiatives is central to meeting the challenges presented by increased fragility in US communities. Here, the authors recommend: 1) More collaboration among families, social researchers, governmental, and non-governmental entities to obtain a true picture of well-being; 2) Increase multi-lingual research at the local level so that families have opportunities to tell their stories of the effects of forced migration, and 3) Consider the development of new frameworks or theories that address adaptive and culturally relevant practices with a social mobility outline for families and communities.

\subsection{Improving Policies}

In the interest of social policy, we recommend a framework (Bolton \& Hernandez, 2016) as it applies to supportive living and learning environments, engaged civic life, empowerment, resilience, and self-awareness. If the model of Adaptive and Culturally-Relevant Practices and the concepts that illustrate family fragility is used as framework, we may better understand barriers that impede changes to educational and social policies and promote social exclusion of those at-risk in impoverished and displaced populations.

\subsection{Conclusions}

From Figure 3, it shows that US families continue to face conditions that render them fragile and vulnerable to the effects of poverty, isolation, conflict, 


\begin{tabular}{|c|c|c|c|c|c|}
\hline $\begin{array}{l}\text { Individuals/ } \\
\text { Families living in } \\
\text { poverty \& social } \\
\text { isolation }\end{array}$ & $\begin{array}{l}\text { Influences: } \\
\text { Education } \\
\text { Health Care } \\
\text { Beliefs } \\
\text { Home } \\
\text { Safety/Security } \\
\text { Laws } \\
\text { Economies }\end{array}$ & $\begin{array}{l}\text { Social Bridges: } \\
\text { Open Education } \\
\text { Unified Societies } \\
\text { Broad Governance } \\
\text { Culturally Germane } \\
\text { Practices } \\
\text { Cross-Cultural Con- } \\
\text { tacts } \\
\text { Value Difference }\end{array}$ & $\begin{array}{l}\text { Economic Bridges: } \\
\text { Inclusion } \\
\text { Representative } \\
\text { Demographics } \\
\text { Advancement } \\
\text { Opportunities } \\
\text { Laws that do not } \\
\text { "Criminalize" }\end{array}$ & $\begin{array}{l}\text { Institutions Value: } \\
\text { Human Diversity } \\
\text { Inclusive Leadership } \\
\text { Mission Orientation }\end{array}$ & $\begin{array}{l}\text { Self-Actualization } \\
\text { Having voice: } \\
\text { Personally } \\
\text { Politically } \\
\text { Economically } \\
\text { Socially }\end{array}$ \\
\hline
\end{tabular}

Figure 3. Adaptive and culturally-relevant practices framework (read from left to right).

environmental disasters, and stressors that greatly affect quality of life. As a move toward cohesion, it is imperative that those affected groups be integrated to mainstream communities with great effort by institutions, education, and governance structures (Ramos, 2016) with programs that address fragility. These fragile communities, often marked by extreme poverty, lack of basic services, and social exclusion, will continue to grow if power structures do not address such conditions (de Boer, 2015).

To address issues of fragility in rural and urban US communities, data were reviewed and analyzed to determine levels of vulnerability. The measurement of success in moving populations away from vulnerability and toward self-sufficiency came from the Millennium Development Goals of reducing persistent poverty and infant mortality, and increasing access to clean water (OECD, 2015). Similar to those countries deemed as "fragile", varying levels of fragility can be observed in US communities. We must identify a means to reach those fragile states within US borders or risk further disenfranchisement (Hernandez \& Bolton, 2015).

Equipping those individuals in fragile communities with marketable job skills should be a strategic goal for the development and growth of those most affected by the growing economic divide separating our society (Hernandez \& Wright, 2015). $17^{\text {th }}$ Surgeon General of the United States, Richard Carmona, said, "When you invest in the poor, you create tax payers", a valuable argument in mitigating fragility. If a model of Adaptive and Culturally-Relevant Practices is used as framework, we may better understand barriers that impede changes to educational and social policies and promote social exclusion of those at-risk in impoverished and displaced populations.

\subsection{Framework for Adaptive and Culturally-Relevant Practices}

\subsubsection{Principles of Approach}

\section{(Bolton \& Hernandez, 2016)}

- Relevance to need for self-actualization and upward mobility to prevent or mitigate social injustice, poverty, and poor health and educational outcomes.

- Partnerships between individuals, communities, institutions (government and private sector). 
- Optimal levels of acculturation and/or integration of "minority" populations

- Continuity through Adaptive and Culturally-Relevant Practices.

\subsubsection{Long-Term Outcomes}

- Risk factors for social, political, academic, and economic failures decrease.

- Individuals integrate with value-chains and provide skilled labor relevant to market demands.

- Laws and policies do not "minoritize" or criminalize citizens, rather they promote and provide security and justice.

- Individuals and families integrate fully into their communities as active participatory members.

\section{References}

Baker, P. H. (2014). Exploring the Correlates of Economic Growth and Inequality in Conflict Affected Environments Fault Lines and Routes of Recovery. Washington DC: CAI Press.

Baker, P. H. (2015). State Fragility and Resilience: Exploring the Correlates of Economic Growth and Inequality in Conflict Affected States. The World Bank Technical Workshop, "Beyond a List", Understanding Fragility and Measurement, Washington DC: CAI Press.

Berube, A. (2014). All Cities Are Not Created Unequal. http://www.brookings.edu/research/papers/2014/02/cities-unequal-berube

Bolton, D. J., \& Dick, S. L. (2016). The Finney County, Kansas Community Assessment Process: Fact Book. NPP eBooks, 10. http://newprairiepress.org/ebooks/10

Bolton, D. J., \& Hernandez, F. (2016). Fragile States: Beyond International Borders and into US Communities. New Prairie Press, Kansas State University Libraries. Adult Education Research Conference. Paper 4.

Collections. https://mospace.umsystem.edu/xmlui/handle/10355/52491

de Boer, J. (2015). Resilience and the Fragile City. Stability: International Journal of Security and Development, 4, Art. 17. http://doi.org/10.5334/sta.fk

Dozi, P., \& Valdivia, C. (2005). Vulnerabilities and Economic Wellbeing of Hispanics in Non-Metro Missouri. Providence, RI: American Agricultural Economics Association Annual Meeting.

Flora, C, B., \& Flora, J. L. (2015). Rural Communities: Legacy + Change (5th ed.). Boulder: Westview Press.

Fund for Peace (2016). Fragile States Index. http://fsi.fundforpeace.org/rankings-2016

Goetz, S. J., \& Rupasingha, A. (2007). Social and Political Forces as Determinants of Poverty: A Spatial Analysis. The Journal of Socio-Economics, 36, 650-671. https://doi.org/10.1016/j.socec.2006.12.021

Hernandez, F. M. (2016). Private Sector Participation and Support of International Development Objectives. Journal of Economics and Sustainable Development, 7, 108-111.

Hernandez, F. M., \& Bolton, D. J. (2015). Moving Up: Communities, Institutions and Plural Societies. University of Missouri, Cambio de Colores 2015 Annual Conference Proceedings, 42-46. https://hdl.handle.net/10355/52495

Hernandez, F. M., \& Wright, J. W. J. (2015). Determining Human Capital Impacts on Economic Growth. Journal of Economics and Sustainable Development, 6, 45-50. 
Ingraham, C. (2014). Our Infant Mortality Rate Is a National Embarrassment. Washington Post.com/WONKBLOG.

https://www.washingtonpost.com/news/wonk/wp/2014/09/29/our-infant-mortality-rat e-is-a-national-embarrassment/

Kaplan, S. (2016). Countering Centrifugal Forces in Fragile States. The Washington Quarterly, 39, 69-82.

https://twq.elliott.gwu.edu/sites/twq.elliott.gwu.edu/files/downloads/TWQ_Spring2016 $=$ Kaplan.pdf https://doi.org/10.1080/0163660x.2016.1170480

Michel, J. (2014). Linking Growth and Governance for Inclusive Development and Effective International Cooperation. Trends in Global Development. Washington DC: Creative Associates International.

OECD (2015). States of Fragility 2015: Meeting Post-2015 Ambitions. Paris: OECD Publishing. https://doi.org/10.1787/9789264227699-en

Ramos, A. (2016). Welcoming Immigrants: An Opportunity to Strengthen Rural Communities. Journal of Extension, 54, Commentary, 3COM1.

https://www.joe.org/joe/2016june/comm1.php

Woolcock, M., \& Narayan, D. (2000). Social Capital: Implications for Development, Theory, and Policy. World Bank Research Observer, 15, 225-249.

https://doi.org/10.1093/wbro/15.2.225

World Bank (2014). Proceedings from Migration and Development Brief, October 6, 2014: Migration and Remittances: Recent Developments and Outlook, Special Topic-Forced Migration. Washington DC: Development Prospects Group.

Submit or recommend next manuscript to SCIRP and we will provide best service for you:

Accepting pre-submission inquiries through Email, Facebook, LinkedIn, Twitter, etc. A wide selection of journals (inclusive of 9 subjects, more than 200 journals)

Providing 24-hour high-quality service

User-friendly online submission system

Fair and swift peer-review system

Efficient typesetting and proofreading procedure

Display of the result of downloads and visits, as well as the number of cited articles

Maximum dissemination of your research work

Submit your manuscript at: http://papersubmission.scirp.org/

Or contact aa@scirp.org 